\title{
Supplemental Information to PUREX Plant Red Oil Evaluation
}

Prepared for the U.S. Department of Energy Office of Environmental Restoration and Waste Management

\section{(Qv) Westinghouse \\ Hanford Company Richland, Washington}

Hanford Operations and Engineering Contractor for the 


\section{LEGAL DISCLAIMER}

This report was prepared as an account of work sponsored by an agency of the United States Government. Neither the

United States Government nor any agency thereof, nor any of their employees, nor any of their contractors, subcontractors or their employees, makes any warranty, express or implied, or assumes any legal liability or responsibility for the accuracy, completeness, or any third party's use or the results of such use of any information, appara!us, product, or process disclosed, or represents that its use would not intringe privately owned rights. Reterence herein to any specitic commercial product, process, or service by trade name, trademark, manufacturer, or otherwise, does not necessarily constitute or imply its endorsement, recommendation, or lavoring by the United States Government of any agency thereot or its contractors or subcontractors. The views and opinions of authors expressed herein do not necessarily state or reflect those of the United States Government or any agency thereot.

This report has been reproduced from the best available copy.

Printed in the United States of Amorica

DISCLM-2.CHP (1.91) 


\title{
Supplemental Information to PUREX Plant Red Oil Evaluation
}

\author{
S. M. Eiholzer
}

Date Published

August 1993

Presented at

Tomsk DOE Headquarters

Team Visit to Hanford

Richland, WA

August 2, 1993

Prepared for the U.S. Department of Energy Office of Environmental Restoration and Waste Management

Copyright License By acceplance of this article. the publisher and/or recpent acknowledges the U S Government s pight to retain a nonexclusive, royally-free license in and to any copyright covering this paper 


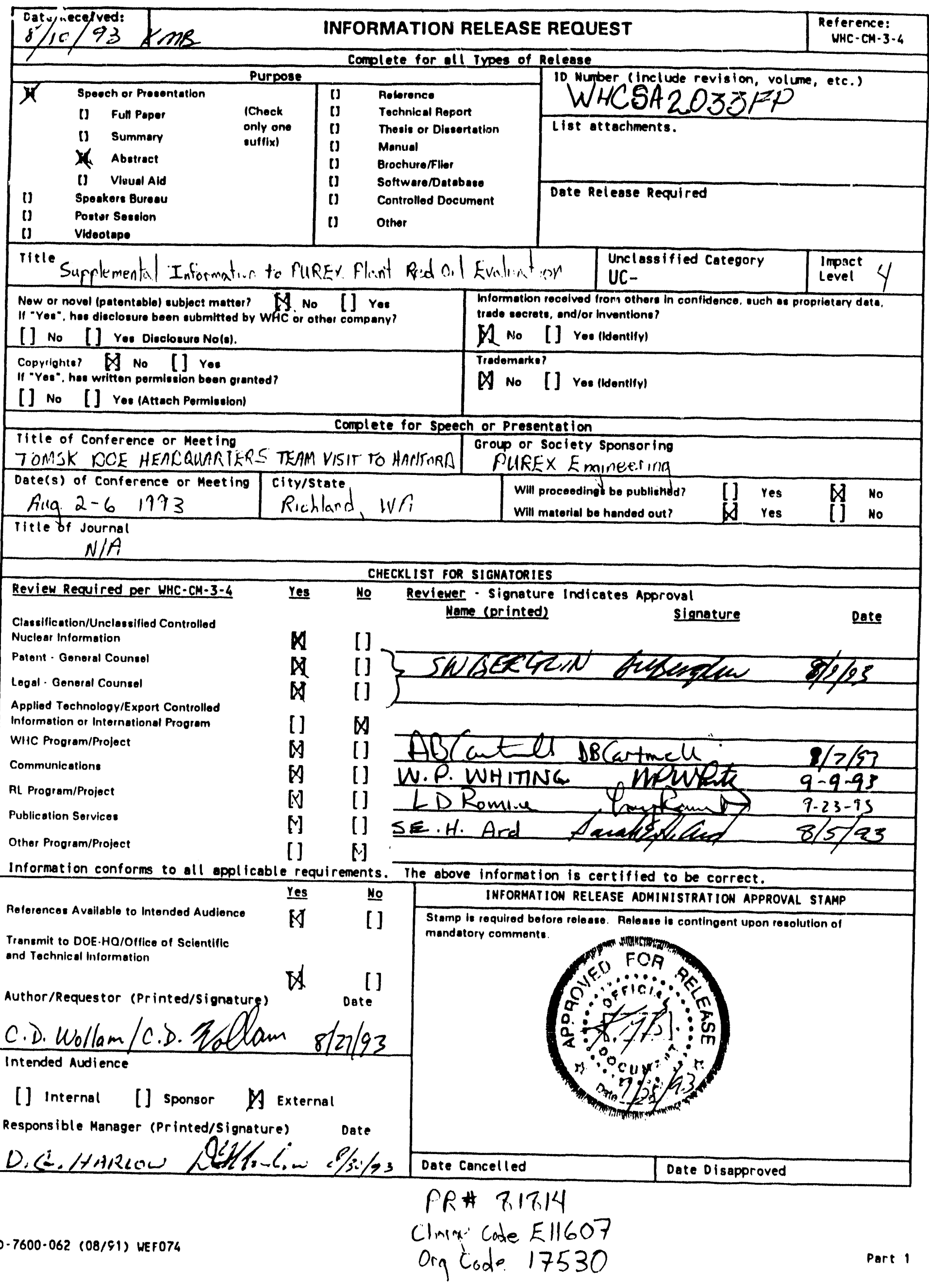




\section{SUPPLEMENTAL INFORMATION TO PUREX PLANT RED OIL EVALUATION}

TOMSK DOE HEADQUARTERS TEAM VISIT TO HANFORD

AUGUST 2, 1993

\section{LIST OF ATTACHMENTS}

Instrumentation Engineering Diagrams:

$\begin{array}{ll}\text { TK-D5 } & H-2-63219 \\ \text { TK-E6 } & H-2-63226 \\ \text { TK-G5 } & H-2 \cdots 63248 \\ \text { TK-R7 } & H-2-63295 \\ \text { TK-U1 } & H-2-63284 \\ \text { TK-U2 } & H-2-63285 \\ \text { TK-P1,P2,P3, \&P4 } & H-2-54805 \text { SHEET 2 OF } 2\end{array}$

"DIP-TUBE MANOMETRY", chapter 2.1 of support document SD-CP-TI-017, pages 2 through 7 


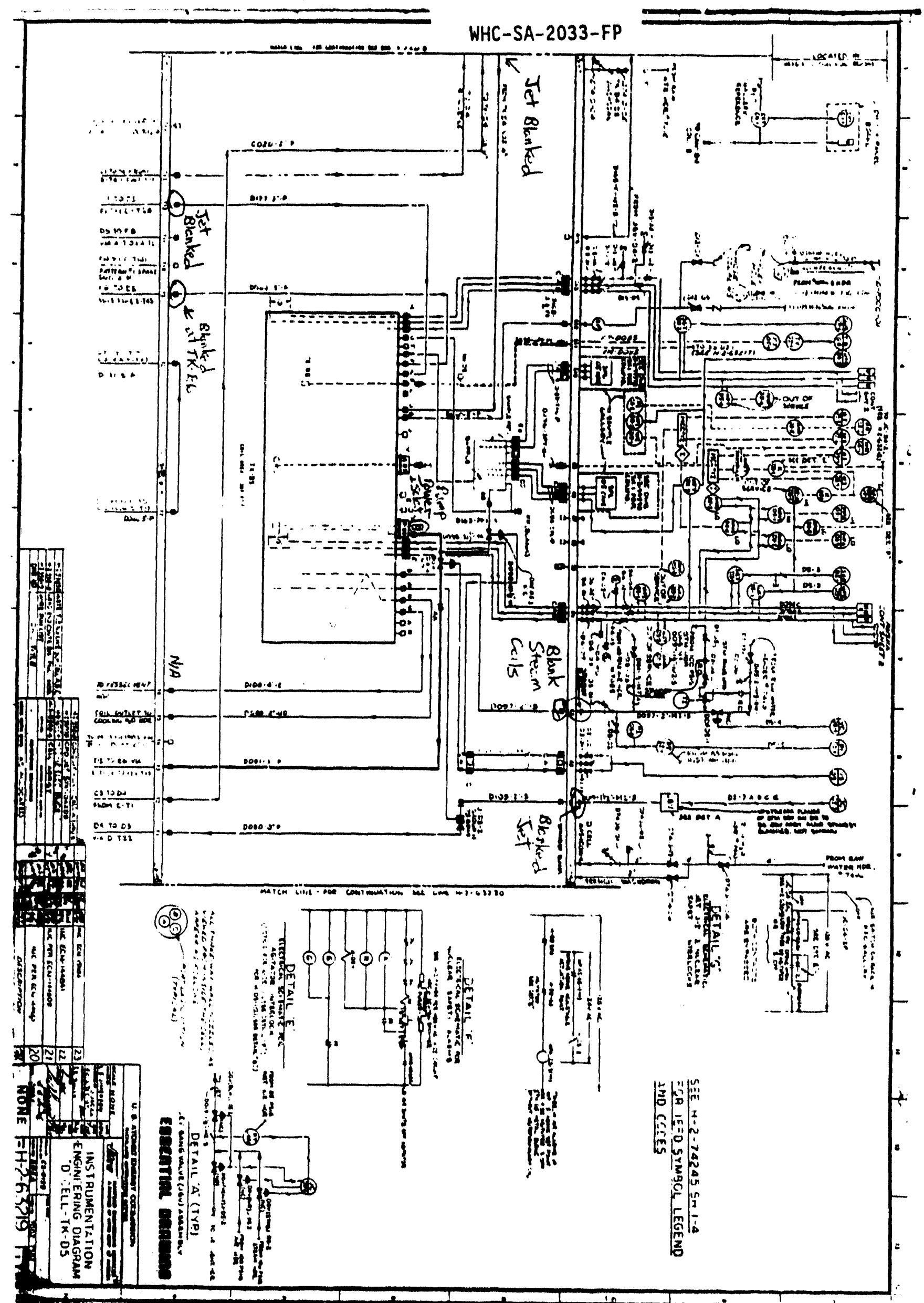




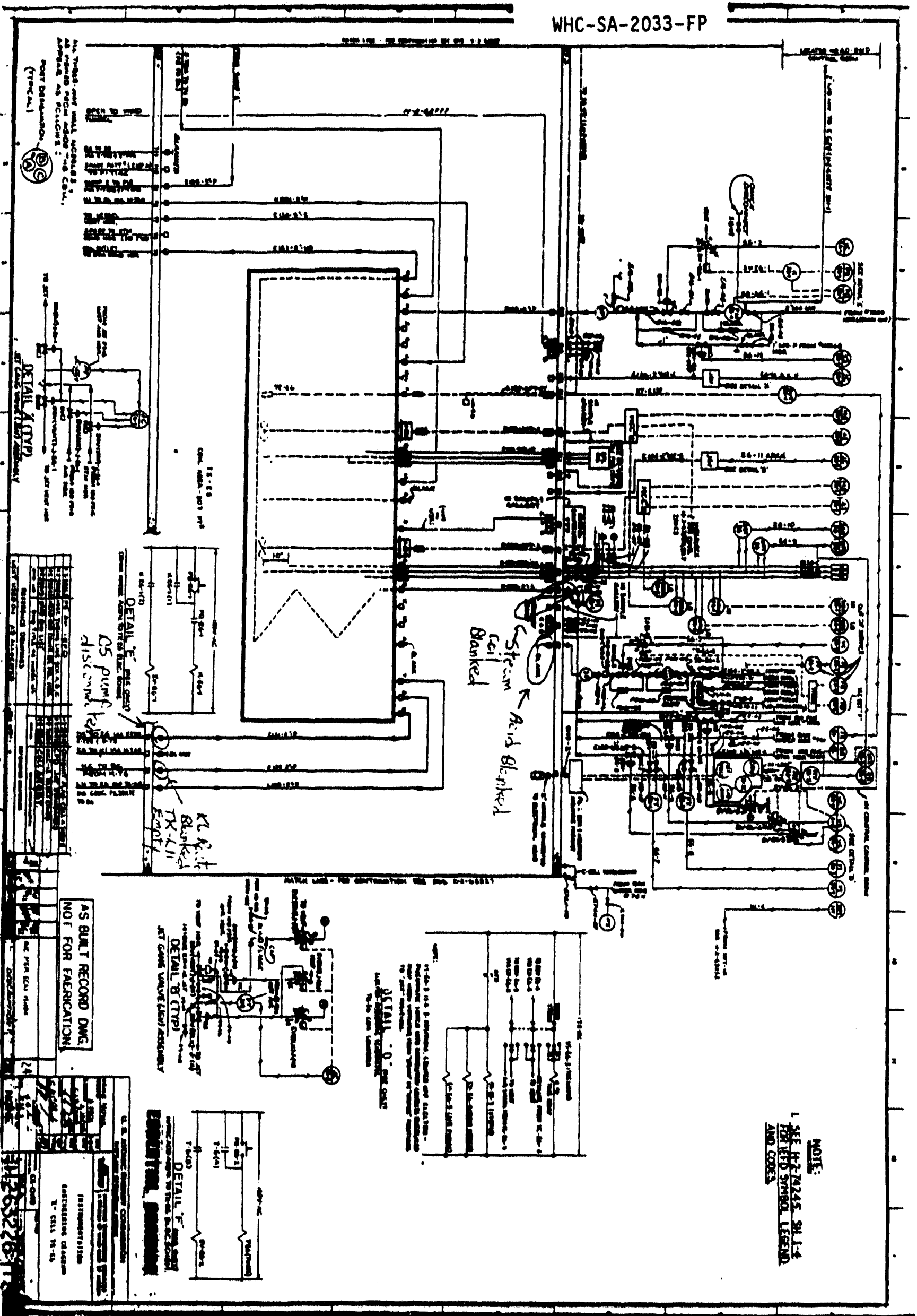

$\therefore 50$ 


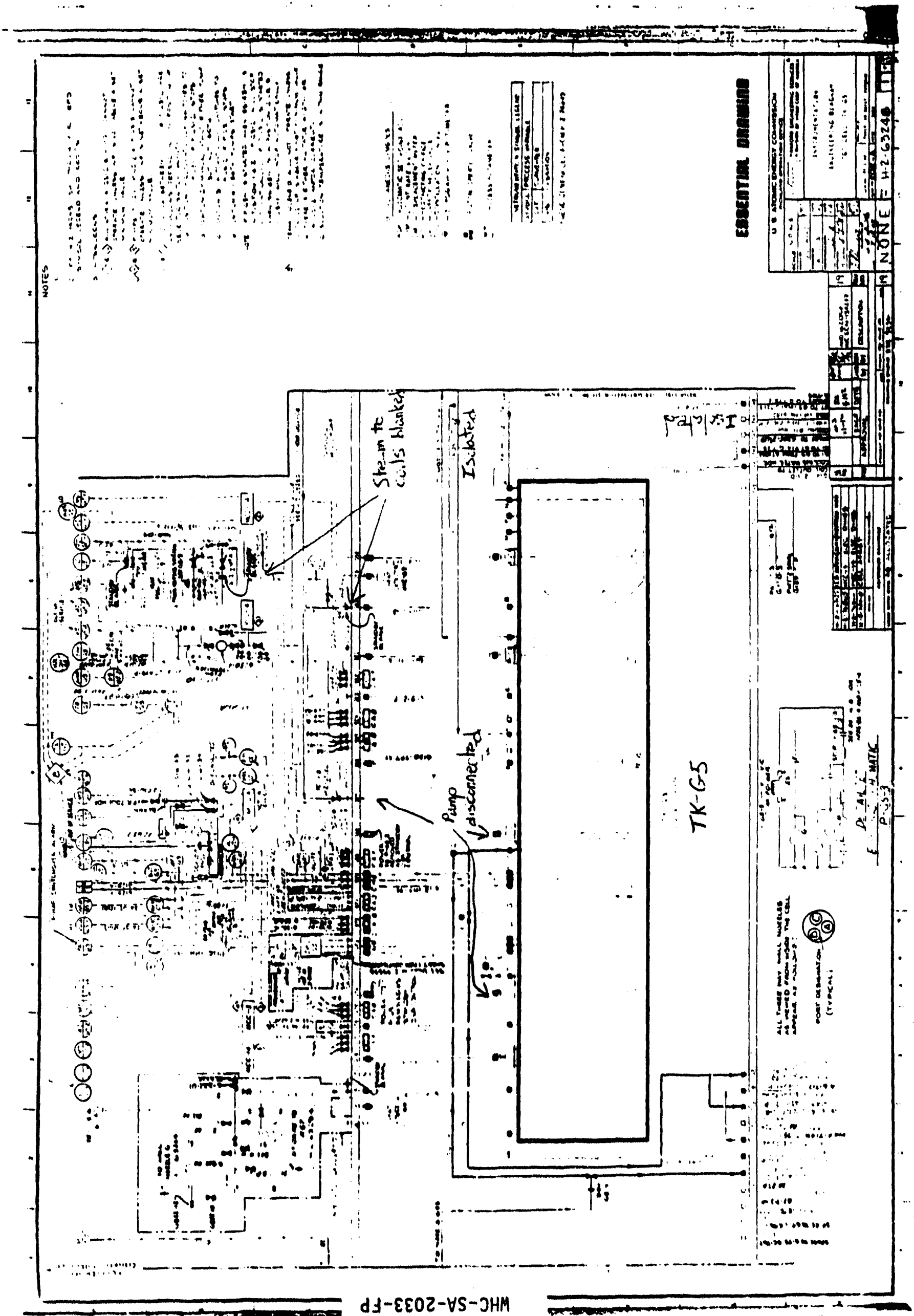




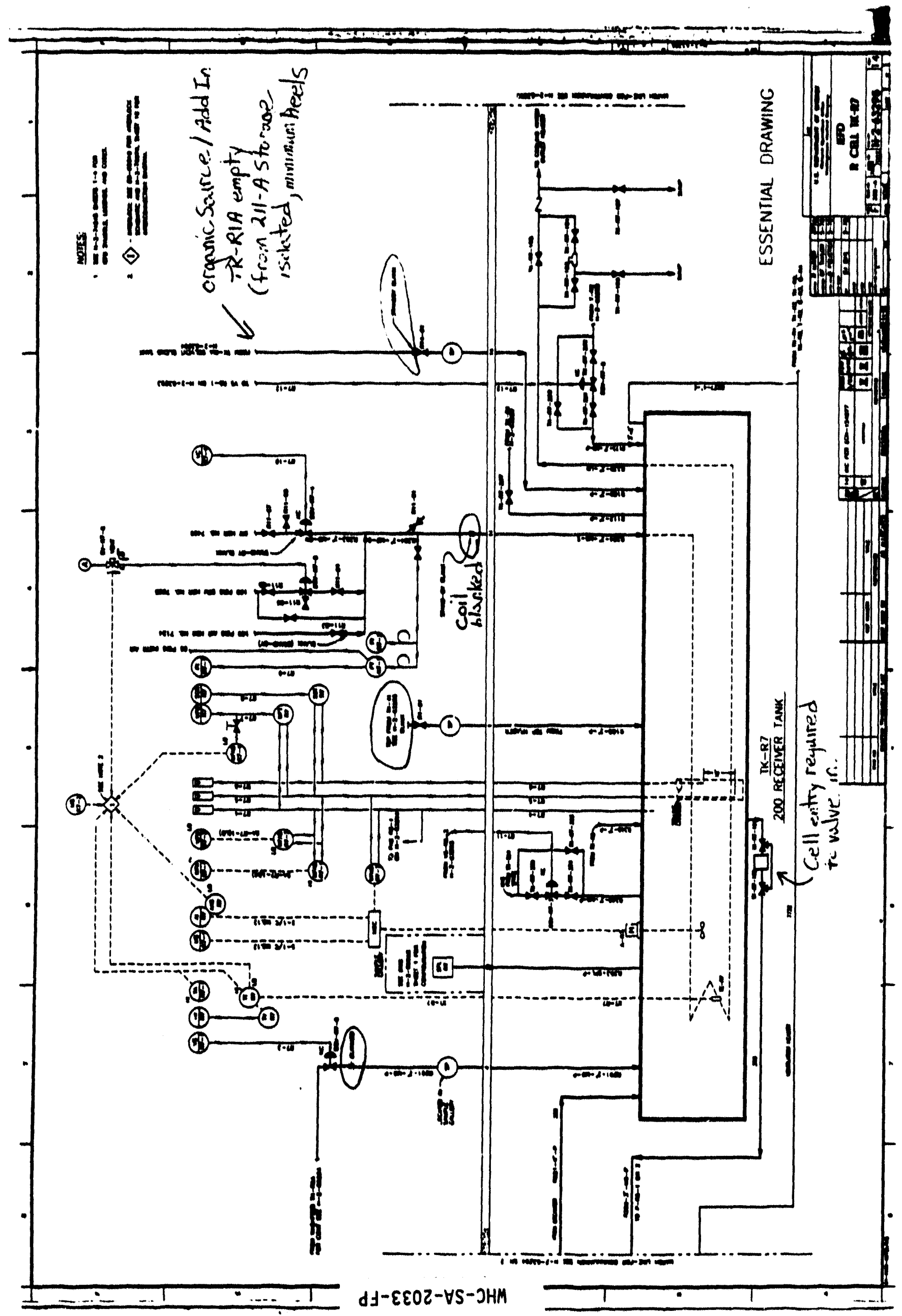




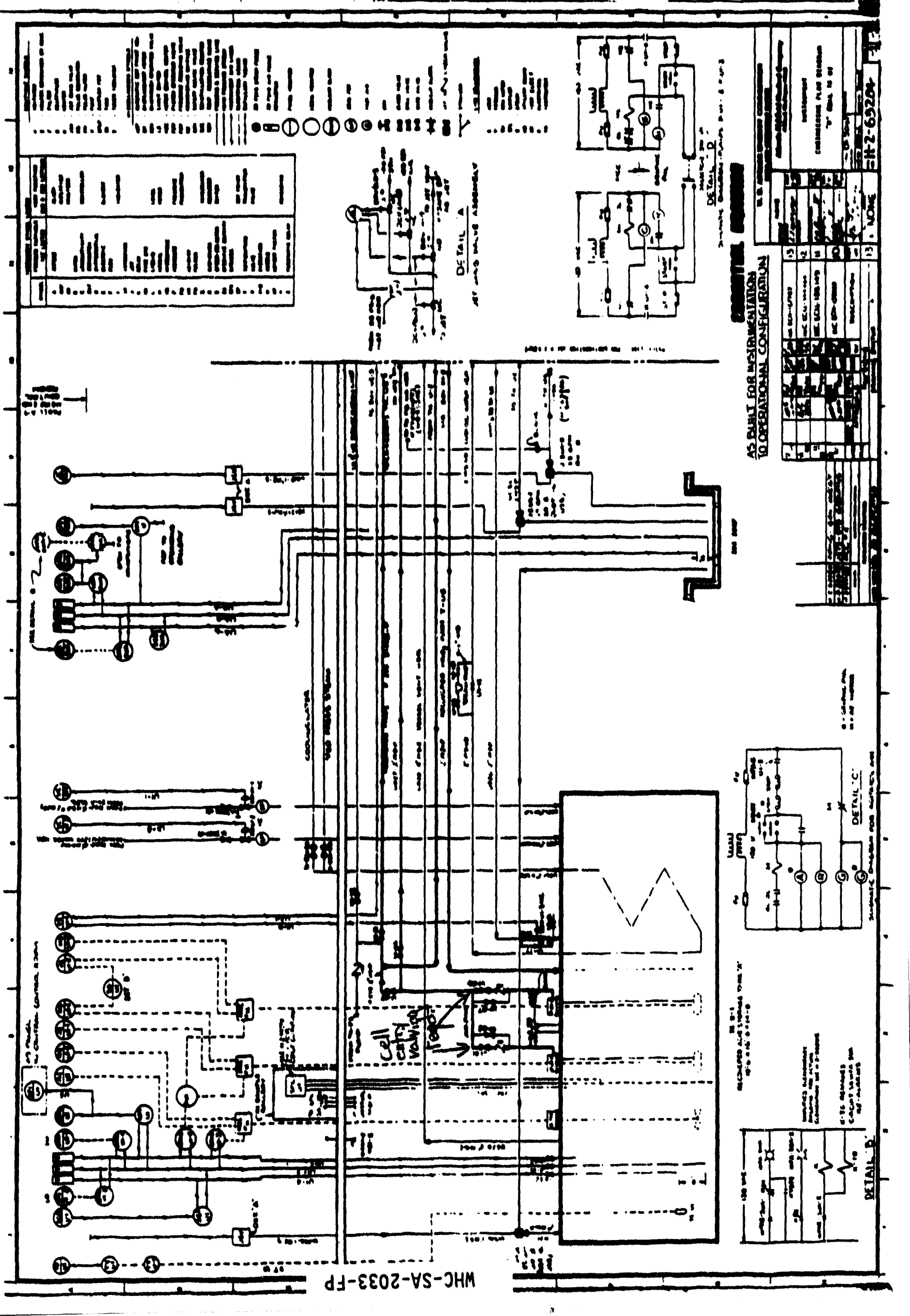




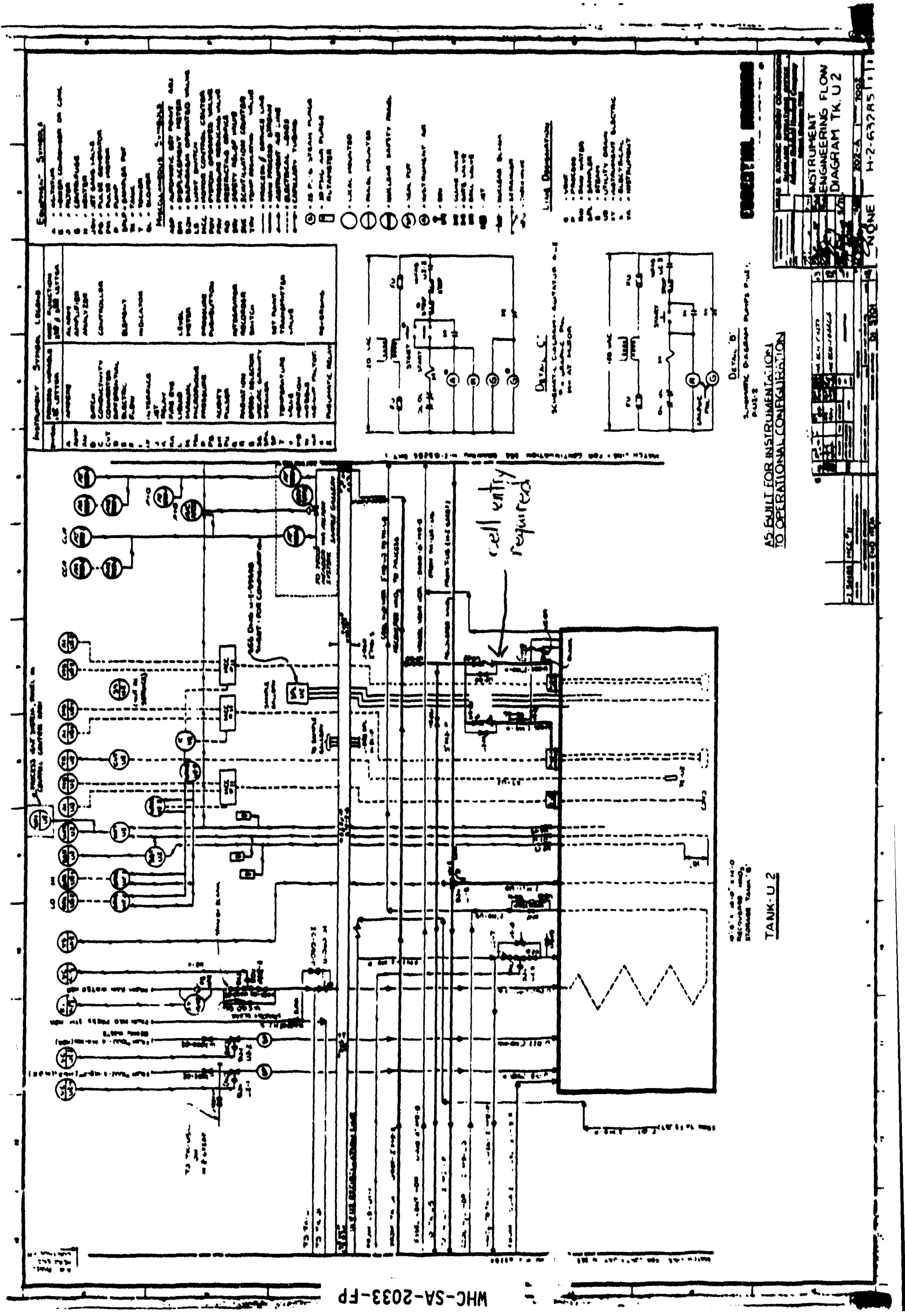




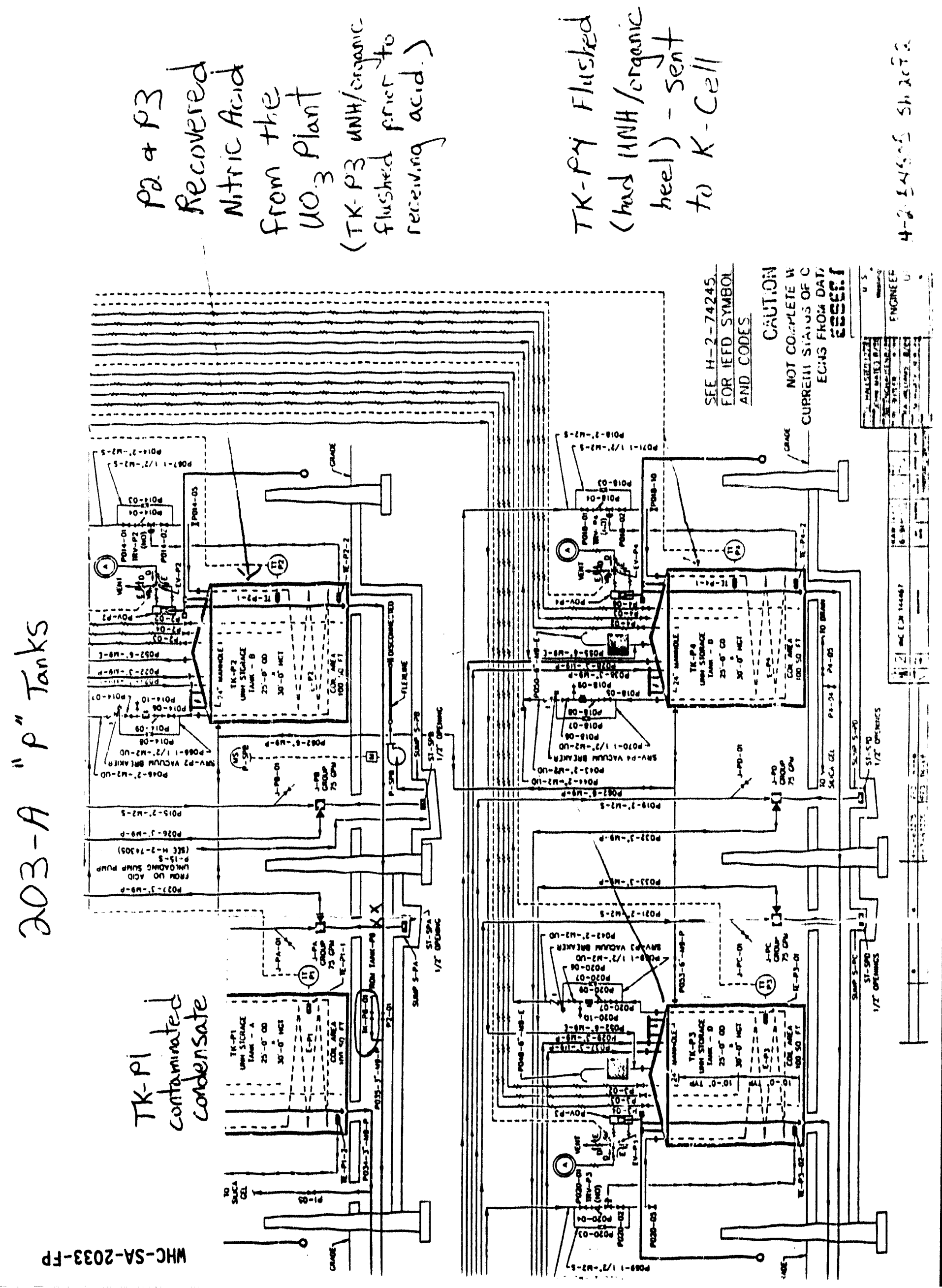




\subsection{GENERIC SYSTEMS DEVICES}

\subsection{DIP-TUBE MANOMETRY}

Dip-tube manometry is a method of measuring the liquid level and solution specific gravity (Sp. gr.) or density in a tank or other vessel at a distance from the tank. Because it is simple and reliable this technique is particularly suited to measuring radioactive liquids contained in tanks behind heavy shielding (such as in the PUREX canyon cells). The principle of dip-tube manometry is to measure the back pressure developed in a tube or pipe that is inserted into a tank and purged with a low flow of air. The back pressure is equal to the hydrostatic head at the end of the tube and is proportional to the liquid level and solution density (see Fig. 2-1). This is read as weight factor (WF) on the panelboard instruments.

Inserting a second tube into the vapor space of the tank and measuring a differential pressure (back pressure) across the two tubes compensates for the effect of the vapor space pressure on the hydrostatic head developed at the end of the first tube (see Fig. 2-2).

A third tube can be installed at a known elevation above the first tube for determination of the liquid specific gravity (see Fig. 2-3). The differential pressure is proportional to the solution density. If the differrential pressures described above are measured in inches of water, the specific gravity and liquid level, LL, can be calculated as follows:

$$
\text { Sp. gr. }=\frac{P_{2}}{H_{2}}
$$

where:

$P_{2}=$ the differential pressure in inches of water between tubes 1 and 3 $\mathrm{H}_{2}=$ the distance between the ends of tubes 1 and 3 , in inches

$$
L L=\frac{P_{1}}{S p \cdot g r \cdot}=\frac{\left(P_{1} \times H_{2}\right)}{P_{2}}
$$

where:

$P_{1}=$ the differential pressure in inches of water between tubes 1 and 2 (generally read as weight factor)

Sp. gr. = as determined in Equation 2-1

The following paragraphs outline some guidelines tliat should be observed for dip-tube manometry to provide reliable and accurate data. 


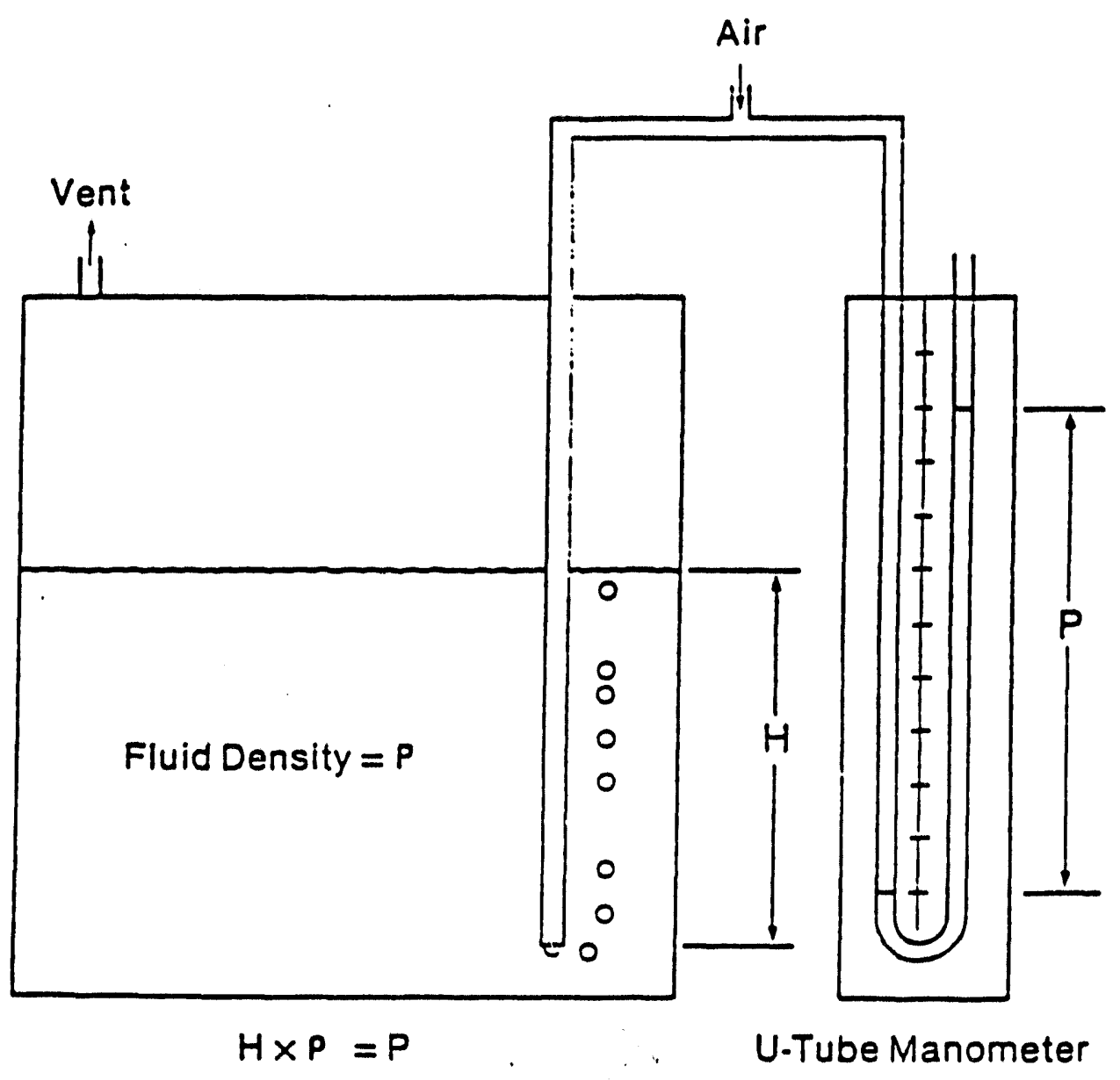

FIGURE 2-1. Dip-Tube Manometer Measurement of Liquid Level. 


\section{WHC-SA-2033-FP}

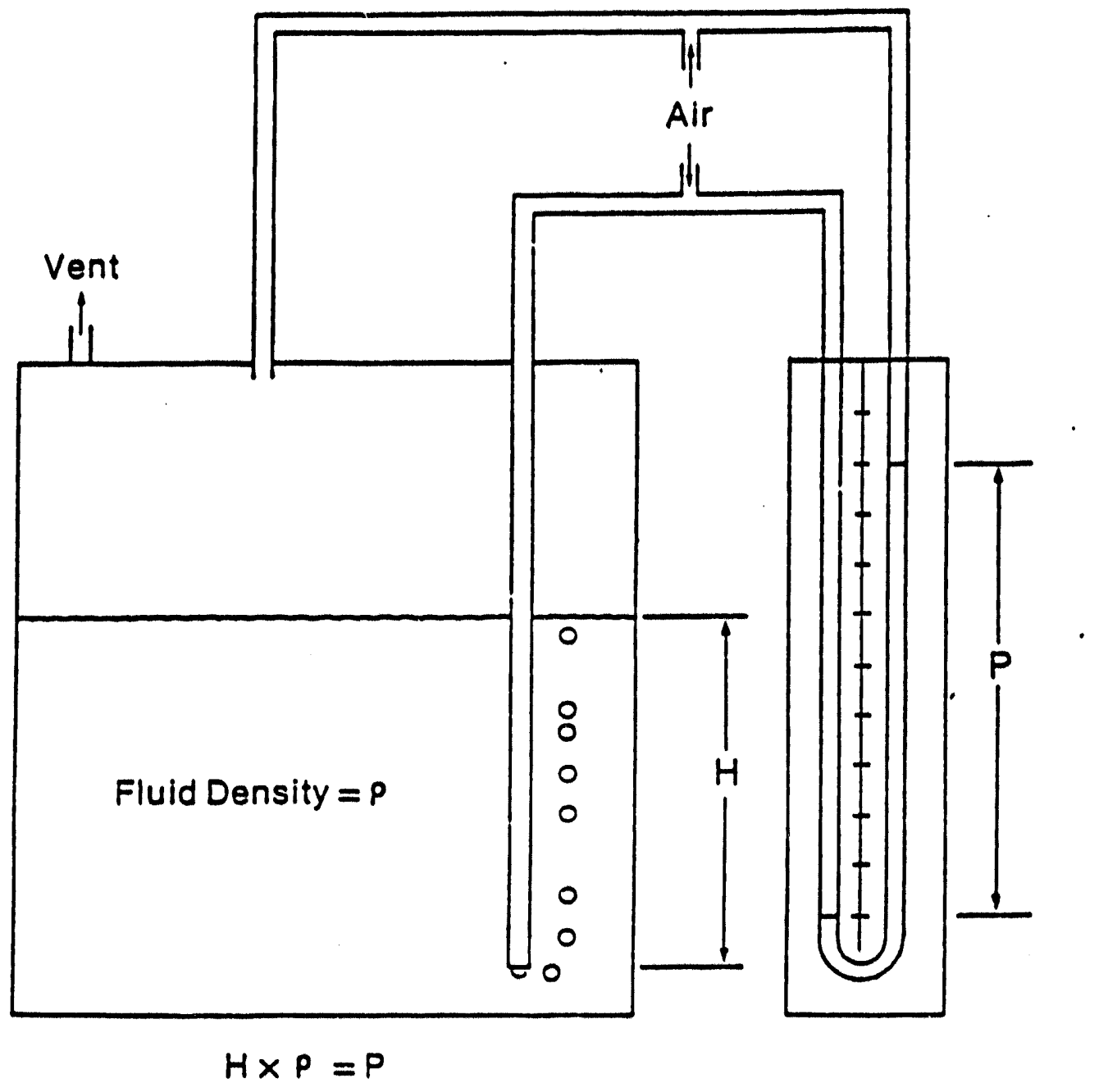

FIGURE 2-2. Improved Dip-Tube Manometry System. 


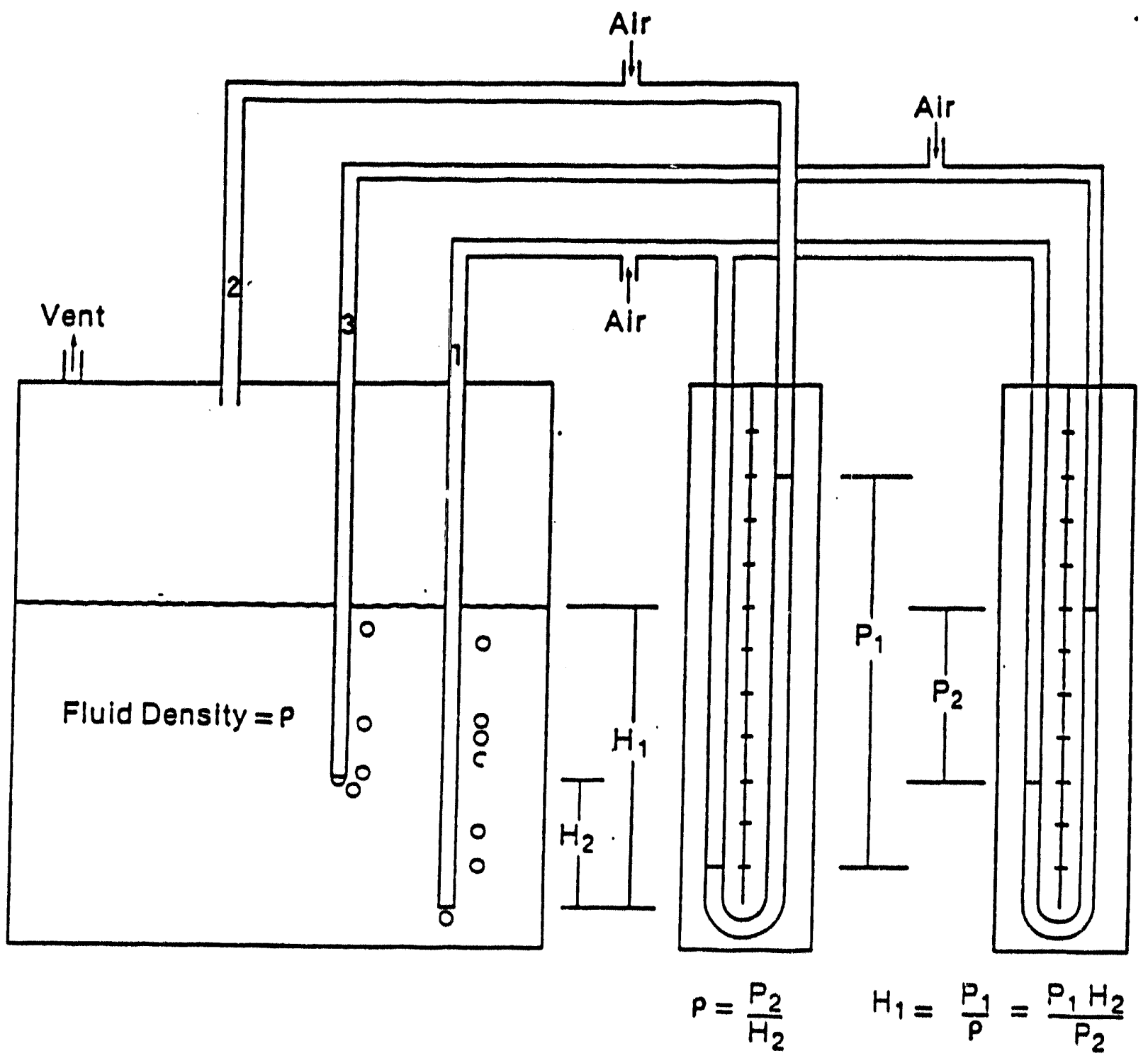

FIGURE 2-3. Density and Level Measurement with Dip-Tube Manometry. 
Appropriately arranged and callbrated differential pressure devices should be used (manometers, pneumatic transmitters, transducers, etc). The range of the liquid level device should be equal to the height of the tank in inches times the specific gravity of the solution normally in the tank. This will allow a\% to $100 \%$ chart or indicator display to correspond to the actual level in the tank.

If the solution specific gravity varies significantly, the highest expected specific gravity should be used. The specific gravity transmitters at PUREX are generally calibrated to cover the range of specific gravities expected in a tank, 1.e., 0.7 to 1.2 or 1.0 to 1.6. The standard specific gravity tube separation is $10 \mathrm{ln}$. For the two ranges cited above, the transmitters are calibrated for a $0 \%$ to $100 \%$ range of $7 \mathrm{in}$. to $12 \mathrm{in}$. of water and $10 \mathrm{in.} \mathrm{to} 16 \mathrm{in.}$. of water. (The "Zero" end is biased or "suppressed" to $7 \mathrm{in.} \mathrm{to} 10 \mathrm{in.}$ of water in these examples).

The air purges on the dip-tubes must be properly set and balanced. The air flowrates are set very low $(0.5$ to $1.0 \mathrm{scf} / \mathrm{hr})$ to minimize frictional pressure drop, which contributes to the back pressure. These flows are measured with miniature visual rotameters and are set with manually adjusted needle valves. The flowrates to the three dip-tubes must be equal to prevent differences in the frictional pressure drop from biasing the readings.

Leaks in the tubing or piping between the transmitter and the tank Jiptubes are a major problem. Small leaks are difficult to find, but can cause significant biases. If the transmitter in question provides the input signal to a controller, make sure the operator has switched the controller to manual before doing leak checks. One way to determine if a leak is present is to temporarily shut off the purge air flow to the three dip-tubes. If the $\Delta P$ readings stabilize and hold, then there are no leaks. If the readings change significantly, either up-scale or down-scale, a leak is present in one or more of the tubes. A leak in the level probe line (tube 1) will cause the liquid level and the specific gravity reading to decrease when the purge is turned off (see Fig. 2-3). A leak in the vapor space probe line (tube 2) will cause the liquid level to increase (the change will probably be very small). A leak in the density probe line (tube 3) will cause the specific gravity reading to increase. To determine if a leak is on the cold side Pipe and Operating (P\&O) Gallery or in the canyon, close the probe line block valve at the gallery wall immediately after shutting off the purge to a confirmed leaking tube. If the change in reading stops, the leak is in the canyon. Resetting the jumper or regasketing it will be necessary to correct the problem. Leak detection in the P\&O Gallery (and elsewhere on the cold side) is generally done using soap solution to check threaded fittings, valve stems, and soldered joints (look for bubbles). Special attention to the flare nuts in the P\&O Gallery is recommended since these have falled in the past (stress-corrosion cracking). When all else fails to locate a leak. check the equalizer valve at the transmitter (crossover between the two dip-tube lines). If this valve leaks, it will look like tubing leak. Make sure all the valves are properly reset and the purges readjusted after these checks. 
Another typical dip-tube problem is the formation of salt crystais inside the end of the submerged tube, resulting in restricted or plugged diptubes. This causes bias in the readings and is particularly troublesome for dip-tube readings taken for accountablilty. Severe cases of salt accumulation are obvious; however, partial pluggage may only be detected as a difference between the in-tank density and the laboratory determined density of a sample taken from the tank (the lab density, which is determined at $200 \mathrm{C}$ to $25^{\circ} \mathrm{C}$, must be corrected to the tank temperature). Salt accumulations can be cleared by "blowing the tubes" (opening the purge rotameter valves fully), steaming, flushing, or by use of a hydraulic ram. Special precautions to prevent blowback and spread of contamination must be observed when attempting to clear the dip-tubes with any of the techniques except the air blow.

When using dip-tube densities and levels for process analysis, do not assume that this data is correct every time. If there is any question about a reading, have an appropriately ranged manometer connected to the dip-tubes to check the readings. It may also be possible to confirm the reading by comparing to readings in another tank containing the same solution.

The dip-tube systems in the PUREX tanks can be used to detect organic layers that may have accumulated in vessels normally containing aqueous solutions. The principal indication of an organic layer is a premature change in the specific gravity recorder as the unagitated tank level is being lowered. The weight factor reading at which the upper specific gravity probe should becone uncovered can be calculated and is equal to the dip-tube separation (usually $10 \mathrm{in.}$ ) divided by the weight factor range, times 100 to convert to weight, times the specific gravity of the solution in the tank. Simply note the corresponding weight factor at which the specific gravity starts to drop and compare it to the predicted weight factor. The difference between these two values is equal to the number of weight factor divisions of organic in the tank.

\subsection{TRANSMITTERS, RECORDERS, AND CONTROLLERS}

Most of these devices are pneumatic-to-pneumatic devices with 3-psig to 15-psig signais from the transmitter to the controller or recorder and from the controller to the control valve. There are a few pneumatic to electric transmitters and some which have other than pneumatic inputs and electric outputs such as the interface indicators (floats). The following points should be kept in mind when using the data from these instruments to monitor plant operation.

- With the exception of the weight factor and specific gravity in unagitated tanks, the recorder readout should not be a perfectly straight line. If it is drawing a straight line, the transmitter or recorder is probably dead.

- Leaks in the sensing and signal lines can be a major problem and are often difficult to find. Concentrate on new or recently removed and replaced fittings when checking for leaks. 
WHC-SA-2033-FP

\section{DISTRIBUTION}

Number of Copies

OUSIIE

10

Hest inghouse Hanford Company

S. M. Etholzer (5)

S6-19

Document Processing and Distribution (2) L8-15

Information Release Administration (3) RI-08 


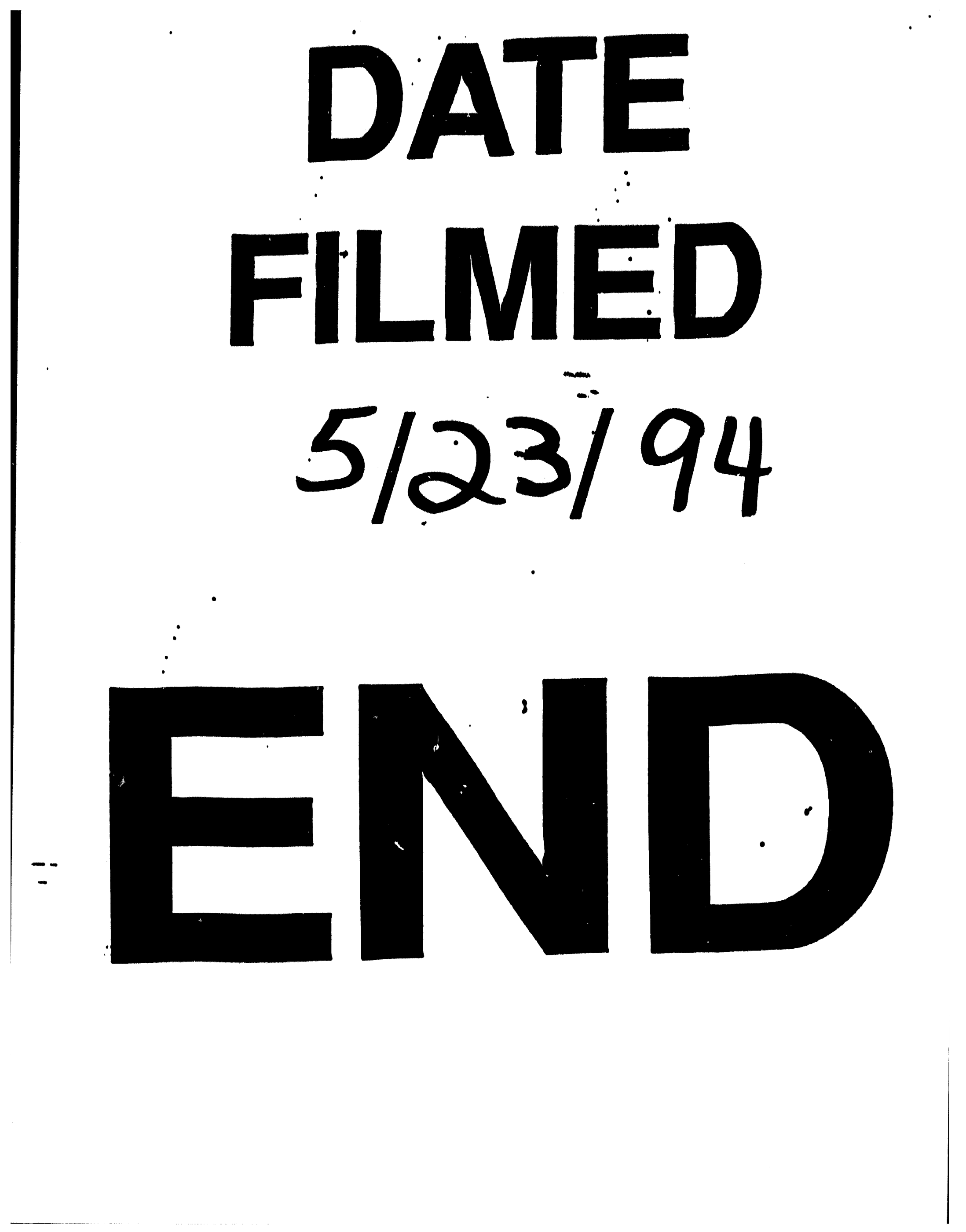




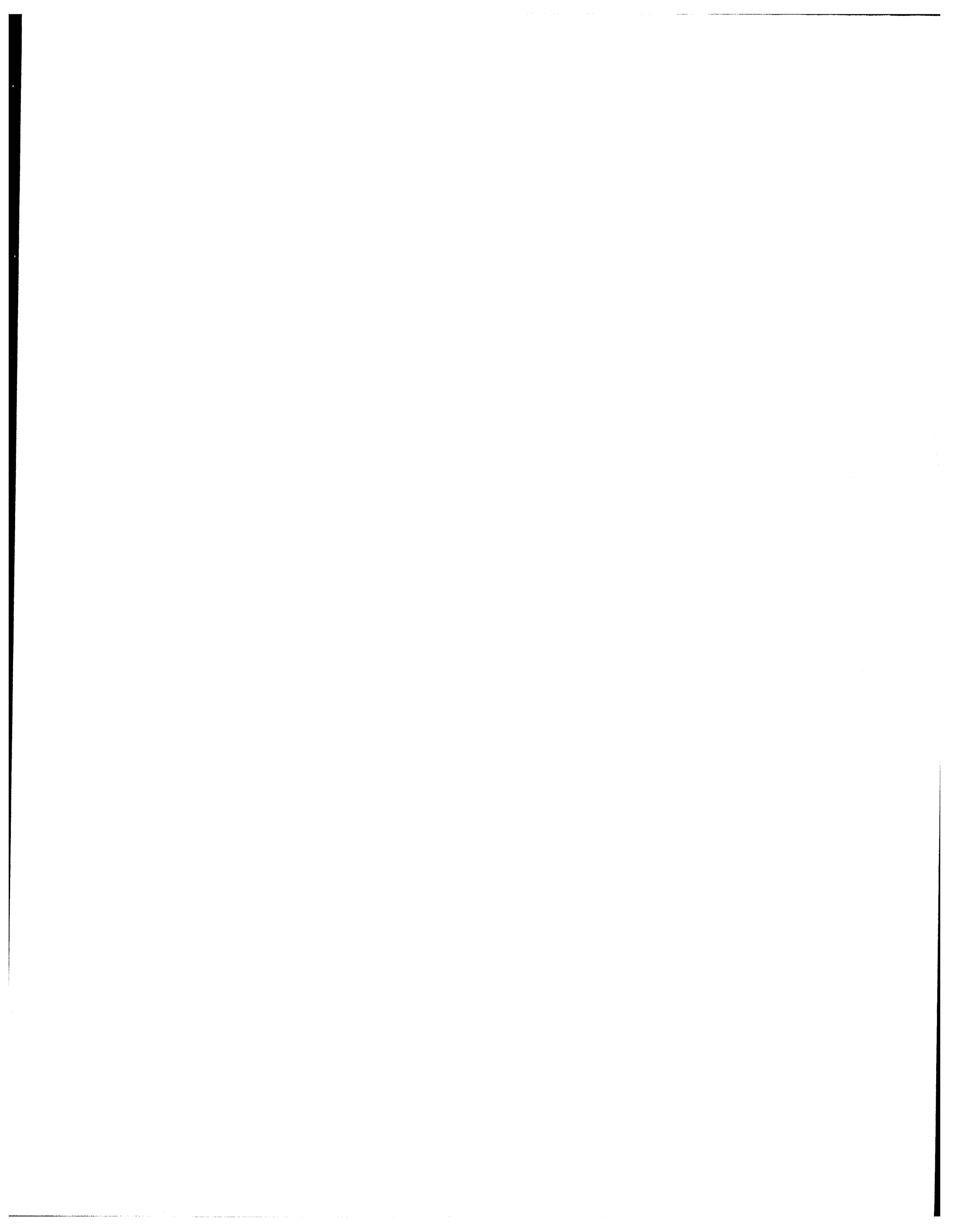

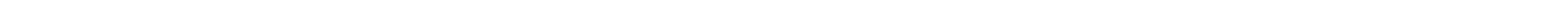

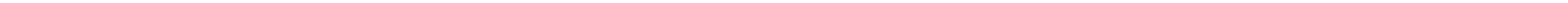

